\title{
Developmental profile and sexually dimorphic expression of Kiss1 and Kiss1r in the fetal mouse brain
}

\author{
John Gabriel Knoll ${ }^{1}$, Colin M. Clay ${ }^{2}$, Gerrit J. Bouma ${ }^{2}$, Timothy R. Henion ${ }^{3}$, Gerald A. Schwarting ${ }^{3}$, \\ Robert P. Millar ${ }^{4,5,6}$ and Stuart A. Tobet ${ }^{2,7 *}$
}

1 Oregon Health and Science University, Portland, OR, USA

2 Biomedical Science, Colorado State University, Fort Collins, CO, USA

${ }^{3}$ Cell Biology, University of Massachusetts Medical School, Worcester, MA, USA

${ }^{4}$ MRC Receptor Biology Unit, University of Cape Town, Cape Town, South Africa

${ }^{5}$ Centre for Integrative Physiology, University of Edinburgh, Edinburgh, UK

${ }^{6}$ Mammal Research Institute, University of Pretoria, Pretoria, South Africa

${ }^{7}$ Biomedical Science and Biomedical Engineering, Colorado State University, Fort Collins, CO, USA

Edited by:

Pei-San Tsai, University of Colorado, USA

\section{Reviewed by:}

Carol F. Elias, University of Michigan, USA

Alexander S. Kauffman, University of California San Diego, USA

Isabelle Franceschini, INRA, France

*Correspondence:

Stuart A. Tobet, Department of

Biomedical Sciences, Colorado State University, 1617 Campus Delivery,

Fort Collins, CO 80523, USA

e-mail: stuart.tobet@colostate.edu
The hypothalamic-pituitary-gonadal axis (HPG) is a complex neuroendocrine circuit involving multiple levels of regulation. Kisspeptin neurons play essential roles in controlling the HPG axis from the perspectives of puberty onset, oscillations of gonadotropin releasing hormone $(\mathrm{GnRH})$ neuron activity, and the pre-ovulatory LH surge. The current studies focus on the expression of kisspeptin during murine fetal development using in situ hybridization (ISH), quantitative reverse transcription real-time PCR (QPCR), and immunocytochemistry. Expression of mRNA coding for kisspeptin (KISS1) and its receptor KISS1R was observed at embryonic (E) day 13 by ISH. At E13 and other later ages examined, Kiss1 signal in individual cells within the arcuate nucleus (ARC) appeared stronger in females than males. ISH examination of agonadal steroidogenic factor-1 (Sf1) knockout mice revealed that E17 XY knockouts $(K O)$ resembled wild-type (WT) XX females. These findings raise the possibility that gonadal hormones modulate the expression of Kiss 1 in the ARC prior to birth. The sex and genotype differences were tested quantitatively by QPCR experiments in dissected hypothalami from mice at E17 and adulthood. Females had significantly more Kiss 1 than males at both ages, even though the number of cells detected by ISH was similar. In addition, QPCR revealed a significant difference in the amount of Kiss1 mRNA in Sf1 mice with WT XY mice expressing less than XY KO and XX mice of both genotypes. The detection of immunoreactive KISS1 in perikarya of the ARC at E17 indicates that early mRNA is translated to peptide. The functional significance of this early expression of Kiss 1 awaits elucidation.

Keywords: kisspeptin, KISS1R, arcuate nucleus, RP3V

\section{INTRODUCTION}

The hypothalamic-pituitary-gonadal (HPG) axis is a complex neuroendocrine circuit responsible for controlling physiological and behavioral reproductive function. The classical description of the circuit begins with gonadotropin releasing hormone (GnRH) neurons, which reside in the basal forebrain/hypothalamus, secreting $\mathrm{GnRH}$ into the hypophyseal portal vasculature where it is transported to gonadotropes in the anterior pituitary $(1,2)$. At least one other cell type is now described as a regulatory component of this circuitry (3). Cells that express the metastasis suppressor gene Kiss1, whose protein product is commonly known as kisspeptin (KISS1), reside in and around two specific locations in the hypothalamus; the rostral periventricular portion of the pre-optic area (POA; sometimes referred to as the RP3V for the rostral periventricular area of the third ventricle), and the caudal region in and around the arcuate nucleus (ARC) $(4,5)$. KISS1 stimulates GnRH neuron activity and Kiss1/KISS1 expression and release is regulated by circulating gonadal hormones $(6,7)$. All evidence to date indicates that cells that synthesize KISS1 are functionally upstream of GnRH neurons.

Much effort has gone into characterizing the role played by KISS1 in the HPG axis. Work with targeted disruption of the genes encoding KISS1 or its cognate receptor KISS1R has shown that KISS1/KISS1R is essential for puberty and adult reproductive competence (8-10). Two populations of kisspeptin neurons have been identified. One population of neuronal cell bodies residing in the RP3V is responsible for mediating the pre-ovulatory $\mathrm{GnRH} / \mathrm{LH}$ surge and positive feedback actions of estradiol, while the more caudal population around the ARC is responsible for controlling the oscillatory $\mathrm{GnRH}$ pulses and negative feedback actions of estradiol (11-13).

Data has revealed that in pre-pubertal and adult animals Kiss 1 expression is regulated by estradiol and testosterone (7). Interestingly, the regulation of Kiss 1 is opposite in the different regions that contain Kiss 1 neurons. In the RP3V, steroid feedback is positive and up-regulates Kiss 1 and in the ARC steroid feedback is 
negative and decreases Kiss1 (14). Several approaches involving genetic modifications have been used to study hormonal influences on Kiss1, including mutations that preclude GnRH synthesis (15), and those that preclude estradiol synthesis (16). The current study takes advantage of transgenic mice in which the steroidogenic factor-1 (Sf1) gene was disrupted. These Sf1 knockouts (KO) mice do not develop fetal gonads and adrenal glands, and as such there is no endogenous fetal sex-steroid production (17). This enables us to determine if Kiss 1 levels are regulated by sex steroid in the fetal brain. Our hypothesis is that if gonadal steroids regulate fetal ARC Kiss1, Sf1 disrupted (KO) XY mice (that develop as phenotypic females) should have more Kiss1 than wild-type (WT) $\mathrm{XY}$, and display expression levels similar to XX mice.

The goal of the current research was to determine the expression pattern of Kiss1 during fetal development and pre-pubertally, as well as to assess Kiss 1 levels in fetal agonadal mice. To accomplish this, both in situ hybridization (ISH) using digoxigenin (DIG)-labeled riboprobes and real-time PCR quantitative reverse transcription real-time PCR (QPCR) were used as complementary approaches to assess regional localization and expression levels, respectively, in brain tissue collected from embryonic day 13 (E13) to post-natal day 35 (P35). Expression of Kiss1 and Kiss1r was detected at E13 and maintained through puberty. Immunohistochemistry (IHC) in fetal and adult tissue revealed a KISS1 expression pattern similar to that of Kiss 1, indicating mRNA is translated into biologically active protein in early development. A sex difference in Kiss 1 expression was seen at specific fetal, postnatal, and peri-pubertal ages, and levels in females always showed significantly higher mRNA levels than males. Examining Kiss1 in fetal brain tissue collected from agonadal Sf1 KO mice, revealed Kiss 1 mRNA expression in XY KO mice resembled WT XX more than WT XY mice, supporting the hypothesis that the differentiated gonad regulates sexual dimorphism in Kiss1 expression even prior to birth.

\section{MATERIALS AND METHODS \\ ANIMALS}

GnRH-eGFP (17) and Sf1 KO (18) mice were housed in the Painter Center of Laboratory Animal Resources at Colorado State University and maintained in plastic cages with aspen bedding (autoclaved Sani Chips, Harlan Teklad, Madison, WI, USA) and environmental enrichments on a 14:10 h light:dark cycle with free access to food (\#8640, Harlan Teklad, Madison, WI, USA) and tap water. Animal care and handling was in accordance with the Colorado State University Animal Care and Use Committee guidelines.

For fetal tissue collections, female and male mice were housed together overnight, and the following day considered to be embryonic day 0 (E0) if vaginal plugs were observed. At the appropriate age, pregnant dams were deeply anesthetized with ketamine/xylazine ( 80 and $8 \mathrm{mg} / \mathrm{kg}$, respectively), embryos were removed individually by Cesarean section, and a crown-rumplength measurement was taken to verify gestational age (approximately $10 \mathrm{~mm}$ at E13, $14 \mathrm{~mm}$ at E15, and $19 \mathrm{~mm}$ at E17) (19). GnRH-eGFP mice were homozygous for eGFP (CBB6/F1 background), and heterozygous $S f-1$ mice (C57BL/6 background) were bred to produce WT and $\mathrm{KO}$ embryos. Tissue from each fetus was collected prior to perfusion for genotyping PCR using primers for Sry to determine genetic sex, and primers for $S f 1$ to identify $S f 1 \mathrm{KO}$ animals (20). After removal, each pup was perfused transcardially with $2 \mathrm{ml} 4 \%$ paraformaldehyde in $0.1 \mathrm{M}$ phosphate buffer (PB; $\mathrm{pH}=7.4$ ) using a hand held $10 \mathrm{ml}$ syringe. Heads were post-fixed overnight in fresh perfusion fixative then stored at $4^{\circ} \mathrm{C}$ in $0.1 \mathrm{M}$ $\mathrm{PB}$ prior to sectioning.

For post-natal tissues, post-natal day (P) 12 and P35 animals were anesthetized with ketamine/xylazine ( 80 and $8 \mathrm{mg} / \mathrm{kg}$, respectively) and perfused with $10 \mathrm{ml}$ Heparin/Saline followed by $10 \mathrm{ml}$ $4 \%$ paraformaldehyde. Heads/brains were post-fixed overnight as above and stored in $0.1 \mathrm{M} \mathrm{PB}$ prior to sectioning.

\section{PROBES FOR IN SITU HYBRIDIZATION}

The templates for generating DIG-labeled riboprobes to Kiss1 and Kiss $1 r$ were obtained from Invitrogen Corporation as cDNAs in the vector pT7T3-Pac, and prepared using DIG RNA labeling mix (Roche Applied Sciences \#11277073910) according to manufacturer's instructions. Antisense riboprobes to Kiss1 were transcribed from an EcoRI-linearized cDNA (GenBank accession \#AA023588) that includes the entire kisspeptin pre-protein coding sequence (base pairs 38-416 of reference sequence NM_178260). Kiss1r antisense riboprobes were generated from EcoRI-linearized cDNA (accession \#BF470621) complementary to base pairs 1716-2842 of Kiss1r reference sequence NM_053244), representing nearly the entire Kiss $1 r$ coding sequence with the exception of 234 base pairs within alternatively spliced exon 4 . Sense probes were generated from the same plasmids linearized with NotI. No reaction product was observed in sections incubated with sense probes using ISH.

\section{IN SITU HYBRIDIZATION}

In situ hybridization was performed as described previously (21) using free-floating tissue sections. Brains were embedded in 5\% agarose containing 1\% diethyl pyrocarbonate (DEPC; Sigma, D5758) and sectioned at $100 \mu \mathrm{m}$ using a vibrating microtome (Leica VT1000s) and collected in $0.05 \mathrm{M}$ phosphate buffered saline (PBS) containing 1\% DEPC. All sections from fetal brains were collected in one mesh-bottomed container (referred to as a boat) while sections from post-natal brains were alternated between two boats. Sections were then treated with $6 \%$ hydrogen peroxide in $0.05 \mathrm{M} \mathrm{PB}$ containing $1 \%$ Tween-20 and 1\% DEPC (PBT) for $1 \mathrm{~h}$ followed by three $5 \mathrm{~min}$ washes in PBT. After washing, sections were treated with $10 \mu \mathrm{g} / \mathrm{ml}$ proteinase K (Sigma, P2308) in PBT for $15 \mathrm{~min}, 10 \mathrm{~min}$ in $2 \mathrm{mg} / \mathrm{ml}$ glycine in PBT, and two $5 \mathrm{~min}$ washes in PBT. Next, sections were post-fixed in $4 \%$ paraformaldehyde $/ 0.2 \%$ glutaraldehyde in PBT for $20 \mathrm{~min}$ and washed twice for $5 \mathrm{~min}$ in PBT. All incubations and washes up to this point were done on a shaker at room temperature. Following post-fixing, sections were transferred to scintillation vials containing $2 \mathrm{ml}$ of $50 \%$ formamide in saline-sodium citrate (SSC; Sigma, S6639) buffer containing $8.8 \mathrm{U} / \mathrm{ml}$ heparin (Sigma, H9399), $0.05 \mathrm{mg} / \mathrm{ml}$ yeast tRNA (Sigma, $\mathrm{R} 5636$ ), and $0.024 \mathrm{mg} / \mathrm{ml}$ dextran sulfate (Sigma, D8906) (collectively pre-hybridization solution) for $1 \mathrm{~h}$ shaking at $60^{\circ} \mathrm{C}$. DIG labeled riboprobes $(1 \mu \mathrm{g} / \mathrm{ml})$ were denatured by incubating for $5 \mathrm{~min}$ in an $85^{\circ} \mathrm{C}$ water bath and added to the vials containing the sections. Probes were hybridized overnight on a shaker at $60^{\circ} \mathrm{C}$. 
The following day, sections were transferred back into boats and washed three times for $30 \mathrm{~min}$ in a 50\% formamide/25\% SSC solution, then three times for $30 \mathrm{~min}$ in $50 \%$ formamide/ $10 \%$ SSC (all while shaking at $60^{\circ} \mathrm{C}$ ). Sections were then washed three times for $5 \mathrm{~min}$ in Tris buffered saline (TBS) containing 1\% Tween20 (TBST) then pre-blocked in 10\% sheep serum in TBST for $1 \mathrm{~h}$ (shaking at room temperature). Sections were then incubated overnight (while shaking at $4^{\circ} \mathrm{C}$ ) in a solution of $1 \%$ sheep serum in TBST containing alkaline phosphatase conjugated anti-DIG antibody (Roche, 11093274910) at a concentration of 1:2000.

On the third day, sections were washed three times for $5 \mathrm{~min}$, then five times for $1 \mathrm{~h}$ in TBST on a shaker at room temperature, and incubated overnight at $4^{\circ} \mathrm{C}$ in TBST. On the final day, sections were washed at room temperature three times for $15 \mathrm{~min}$ in a solution of $0.1 \mathrm{M} \mathrm{NaCl}, 0.1 \mathrm{M}$ Tris $(\mathrm{pH}=9.5), 0.05 \mathrm{M} \mathrm{MgCl}_{2}$, and $1 \%$ Tween-20 (collectively NTMT). Sections were then incubated on a shaker in the dark at room temperature in a solution containing $10 \%$ polyvinyl alcohol, $1 \mathrm{mM}$ Levamisol (Vector Laboratories, Burlingame, CA SP5000, USA), 2\% NBT/BCIP (Roche, $11681451001), 0.1 \mathrm{M}$ Tris $(\mathrm{pH}=9.5), 0.1 \mathrm{M} \mathrm{NaCl}$, and $0.005 \mathrm{M}$ $\mathrm{MgCl}_{2}$ (color detection mix). Sections were left in the color detection mix until dark purple reaction product was visible under a dissecting microscope, at which point the reaction was terminated for all tissues of the same age. To stop the color reaction, sections were washed twice for $5 \mathrm{~min}$ in NTMT in the dark, incubated in $0.1 \mathrm{M}$ TBS containing $0.001 \mathrm{M}$ EDTA for $30 \mathrm{~min}$, and finally twice for $10 \mathrm{~min}$ in PBT (on a shaker at room temperature). The procedures were designed to process all tissues at the same time to facilitate qualitative comparisons between different genotypes.

\section{IMMUNOHISTOCHEMISTRY}

Immunocytochemical procedures were standard and performed as described previously (22). Briefly, $50 \mu \mathrm{m}$ serial sections from $4 \%$ paraformaldehyde perfusion-fixed peri-pubertal (P35) or fetal (E17) brains were cut using a vibrating microtome (Leica VT1000s) and collected into mesh-bottomed boats. Sections were pretreated with $0.1 \mathrm{M}$ glycine then $0.5 \%$ sodium borohydride in $0.05 \mathrm{M}$ PBS. Sections were blocked with 5\% normal goat serum (NGS) and 1\% hydrogen peroxide in $0.05 \mathrm{M}$ PBS. Sections were incubated with rabbit derived KISS1 antibody directed against rodent kisspeptin-10 (provided by Dr. Alain Caraty) at a final dilution of 1:10,000 for two nights (23). Primary antibody was localized with a biotinylated donkey anti-rabbit secondary antibody (Jackson Immunoresearch, 711-065-152) used at a concentration of 1:2500 for $2 \mathrm{~h}$. Signal was amplified using the Vectastain ABC Elite reagents (Vector Laboratories, PK6100) at a concentration of 1:330 for $1 \mathrm{~h}$. Finally, the reaction was visualized using diaminobenzidine (DAB; 0.025\%)/nickel ammonium sulfate $(0.2 \%)$ to produce a dark purple/black reaction product. Although it has been reported that the antiserum does not cross react with related RF-amide peptides such as RFRP1 and RFPR-3 $(9,10)$ this was not fully verified as some cells were detected in regions such as the dorsomedial hypothalamus where no cells were detected by ISH (Data not shown). Specificity of the IHC was established by omission of the primary antibody.

\section{DUAL-LABEL ISH/IHC}

Dual-label ISH/IHC experiments were carried out exactly as single-label experiments with the exception that the two protocols were run in series. In this case, ISH for Kiss1r was performed first, followed immediately by IHC for GnRH. Primary antibody for these experiments was rabbit-anti-GnRH (Affinity Bioreagents \#PA1-121) used at a concentration of 1:200. For visualization, the IHC was developed using Cy3-conjugated streptavidin (Jackson Immunoresearch \#016-160-084) at a concentration of 1:500.

\section{QUANTITATIVE REVERSE TRANSCRIPTION REAL-TIME PCR}

Tissue was collected fresh from fetuses (E17) and adults ( P P0) and flash frozen on dry ice then stored at $-80^{\circ} \mathrm{C}$ until homogenized for RNA isolation. Brains were removed from GnRH-eGFP and Sf1 KO mice in ice cold DEPC PBS. Genetic sex was confirmed by PCR for the presence of Sry. Pregnant mice were anesthetized with a mixture of Ketamine and Xylazine $(80$ and $8 \mathrm{mg} / \mathrm{kg}$ respectively) and embryos were removed individually by Caesarian section. Following brain removal, a hypothalamic block was dissected (caudal to the optic chiasm and rostral to the mammillary body) and a small ( $<10 \mathrm{mg}$ ) wedge of the mediobasal hypothalamus was collected for analysis by making a bilateral triangular excision starting at the middle of the third ventricle and extending to the lateral boundary of the hypothalamus. Adult mice were anesthetized with a mixture of Ketamine and Xylazine ( 80 and $8 \mathrm{mg} / \mathrm{kg}$ respectively) and the brains were dissected out, blocked in the coronal plane rostral to the optic chiasm and caudal to the mammillary bodies, then cut coronally midway between the optic chiasm and the median eminence (ME) to divide the block into rostral and caudal portions. For the rostral portion containing the periventricular portion of the pre-optic area/anterior hypothalamus, a bilateral triangular excision was made extending from the center of the anterior commissure to the basolateral boundary of the hypothalamus. For the caudal portion containing the ARC, an excision similar to that made for the embryos was collected. At both ages cortical pieces were taken for negative controls in the QPCR assays. All dissections were performed using a stereo dissecting microscope.

RNA was isolated using the Qiagen RNeasy Mini Kit (Qiagen Sciences, \#74104). Briefly, excised brain pieces were pulverized using a motorized tissue grinder and RNase free tubes and disposable pestles (VWR cat. \#47747-370 and \#47747-366), then homogenized in the supplied homogenization buffer and procedures were followed according to manufacturer's instructions. Once eluted, the RNA concentration and purity of each sample was determined by spectrophotometry and samples were stored at $-80^{\circ} \mathrm{C}$ until reverse transcription (RT).

For GnRH-eGFP mice, RT was performed using the Thermo Verso RT kit (Fisher cat \#AB1453B) using random hexamer primers for first strand synthesis according to manufacturer's instructions. For $S f 1 \mathrm{KO}$ mice, RT was performed using the qScript cDNA Synthesis kit (Quanta Biosciences cat \#95047) which contains a mixture of random hexamers and oligo(dT). To insure uniformity between samples, all RNA isolates were diluted to $100 \mathrm{ng} / \mu \mathrm{l}$ of which $5 \mu \mathrm{l}$ (500 ng total RNA) was added to each $20 \mu \mathrm{l}$ reaction. RT was performed less than $24 \mathrm{~h}$ prior to QPCR to minimize potential sample degradation. 
For GnRH-eGFP animals, QPCR was performed using HotStart-IT SYBR Green QPCR Master Mix (2X; USB Corporation, Cleveland, $\mathrm{OH} 75762$, USA). According to the HotStart-IT protocol, $20 \mu \mathrm{l}$ reactions were run of with $2 \mu \mathrm{l}$ cDNA. For $S f 1$ KO animals, QPCR was run using Light Cycler 480 SYBR Green I Master Mix kit (Roche cat \#04-707-516001) using $4 \mu \mathrm{l}$ cDNA in each $20 \mu \mathrm{l}$ reaction. All QPCR experiments were performed in a LightCycler 480 system (Roche Applied Sciences). Cycling parameters were as follows: hot start at $95^{\circ} \mathrm{C}$ for $1 \mathrm{~min} ; 45$ cycles of amplification/quantification at $95^{\circ} \mathrm{C}$ for $10 \mathrm{~s}, 60^{\circ} \mathrm{C}$ for $30 \mathrm{~s}$, and $72^{\circ} \mathrm{C}$ for $30 \mathrm{~s}$ during which time fluorescence was measured. Melting curve analysis was performed using continuous fluorescence acquisition from $65-97^{\circ} \mathrm{C}$. These cycling parameters generated single amplicons for both primer sets used according to the presence of a single melt peak. Primers were designed to amplify intron spanning regions of Kiss 1 and Rn18s (reference gene) to investigate the gene of interest and monitor amplification efficiency. The two sets of primers used for this experiment were as follows: Kiss 1 forward 5'-TGATCTCAATGGCTTCTTGGCAGC$3^{\prime}$ and reverse $5^{\prime}$-CTCTCTGCATACCGCGATTC CTTT-3'; Rn18s forward $5^{\prime}$-AGGGGAGAGCGGGTAAGAGA- $3^{\prime}$ and reverse $5^{\prime}$ GGACAGGACTA GGCGGAACA-3'.

For absolute quantification of kisspeptin transcript, the same plasmid used to generate the Kiss 1 probe was used as a standard. Since each plasmid contains a single copy of the Kiss1 gene, and using an approximation of the total molecular weight of the plasmid ( $\sim 3.7 \mathrm{E}-12 \mu \mathrm{g} /$ copy) the concentration of plasmid was calculated in terms of number of copies per $\mu 1$ of solution. A 10 -fold serial dilution series was used to generate a standard curve ranging from $\sim 1 \mathrm{E}^{11}$ copies $/ \mu \mathrm{l}(0.4 \mu \mathrm{g} / \mu \mathrm{l})$ to $\sim 100$ copies $/ \mu \mathrm{l}$. This dilution series was run in the same plate as each experiment and was used to generate a standard curve from which the concentration (in number of copies/well) was calculated for each sample. This number was then used to calculate the number of copies of Kiss 1 in E17 and adult male and female brains [copies/well $\div$ (microliter cDNA/well $)=$ copies $/$ microliter $\mathrm{cDNA} \div($ microliter $\mathrm{RNA} / 20 \mu \mathrm{l}$ cDNA $)=$ copies $/$ microliter $\quad$ RNA $\times$ Dilution $\quad$ Factor $=$ copies $/$ microliter RNA (undiluted) $\times$ Total RNA Volume $=$ Total Copies/ dissection].

To control for contamination, several controls were used. First, pieces of cortex not expected to express Kiss1 were collected from each brain at the time of tissue collection. These tissues were treated the same as all other tissue pieces and did not generate a signal above background during QPCR. During the RT, two additional controls were used; one reaction with no RNA, and one with RNA (from an adult female rostral POA) but no reverse transcriptase. Controls from each of the previous steps were run through all subsequent steps. Real-time PCR controls included all of the previous controls and one reaction containing no cDNA (water control). None of the negative controls produced a signal above background in QPCR (data not shown). Finally, standards and samples were run in triplicate to verify accuracy; calculated crossing point variance was below $2 \%$ for replicated samples.

\section{STATISTICAL ANALYSIS}

For each age group in each experiment three animals of each sex and genotype from a minimum of two different litters were used for quantitative analysis. To determine the number of cells expressing kisspeptin, all cells (with obvious nuclear voids) with visible reaction product in all sections from a given brain were manually counted at high magnification by an investigator blind to the sex of each animal. For fetal brains this meant counting all sections from the entire brain (all sections collected in a single boat) while for older animals it meant counting all sections from half of the brain (sections were alternated between two boats). The reason for collecting all sections from the embryonic brains was to ensure that important sections were not lost due to the smaller size of the brains. For comparison purposes, the total number of cells counted for each embryonic brain was divided in half to generate the equivalent of the number of cells per half-brain. This method was validated by alternating sections from a subset of fetal brains into two boats and counting the number of cells per half-brain; the resultant average was approximately equal to the average of half the total cells per whole brain.

For QPCR, the crossing point was determined according to the absolute quantification/second derivative maximum method in the LightCycler 480 SW 1.5 software. From this number, the total copy number was calculated based upon the previously described standard curve. To verify the results of the standard curve absolute quantification method, relative expression analysis was performed by normalizing Kiss1 to Rn18s signal. Both methods generated similar results and the absolute quantification method results were selected for presentation. Cycling parameters were set up such that the exponential amplification phase had been reached for all positive samples ( 45 cycles total). Any sample that did not exhibit an appropriate amplification curve, a single melt curve, or that came up after 40 cycles was assumed to be a false signal and was not analyzed. Negative control samples were never observed to generate a signal before 40 cycles.

Statistical analysis was performed using SPSS 13.0 or JMP 10.0 for Mac OSX. For cell count analysis, the total number of cells per half-brain and the sex of the animal were analyzed by twoway ANOVA for sex and age. For QPCR data from $S f-1$ embryos two-way ANOVA for sex and genotype was used, with Least Square Means Student's $t$ as a post hoc test. For adult animals, even though there were two regions per animal, due to the greater variance in the rostral/POA region compared to the caudal/ARC region, oneway ANOVA was conducted on the rostral region separately from a two-way analysis in the caudal/ARC region.

\section{RESULTS}

\section{Kiss1/KISS1 AND Kiss1r REGIONAL LOCALIZATION IN THE FETAL BRAIN}

Kiss1 was detected by ISH at E13 in a few cells (arrows in Figure 1 left) near the ME. Two days later (E15) the total number of cells expressing Kiss 1 had greatly increased (from approximately 30 cells/half-brain to approximately 400 cells/half-brain), although the distribution remained similar (Figure 1). Cells containing Kiss 1 were found in approximately eight sequential sections, representing a distance of greater than $800 \mu \mathrm{m}$ in all ages examined.

Expression of Kiss1r was detected at E13 in both sexes by ISH. At this age, the only cells containing Kisslr were found in the nasal compartment in a pattern similar to the pattern of migrating GnRH neurons. By E15 a large proportion of this population 


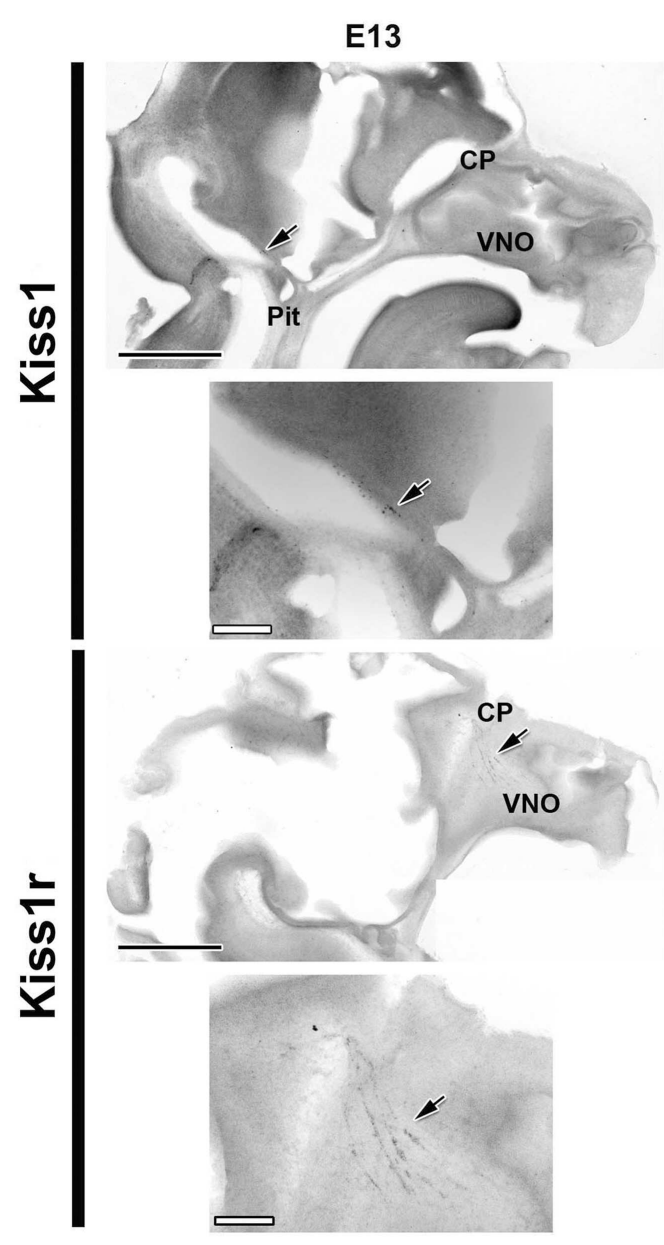

FIGURE 1 | Kiss1 and Kiss1r are expressed as early as E13. Developmental changes in the expression of Kiss 1 (top four images) and Kiss1r (bottom four images) are shown in digital images from sagittal sections of female mice at E13 (left) and E15 (right). Smaller images are higher magnifications of the same sections displayed immediately above them. Note the change in

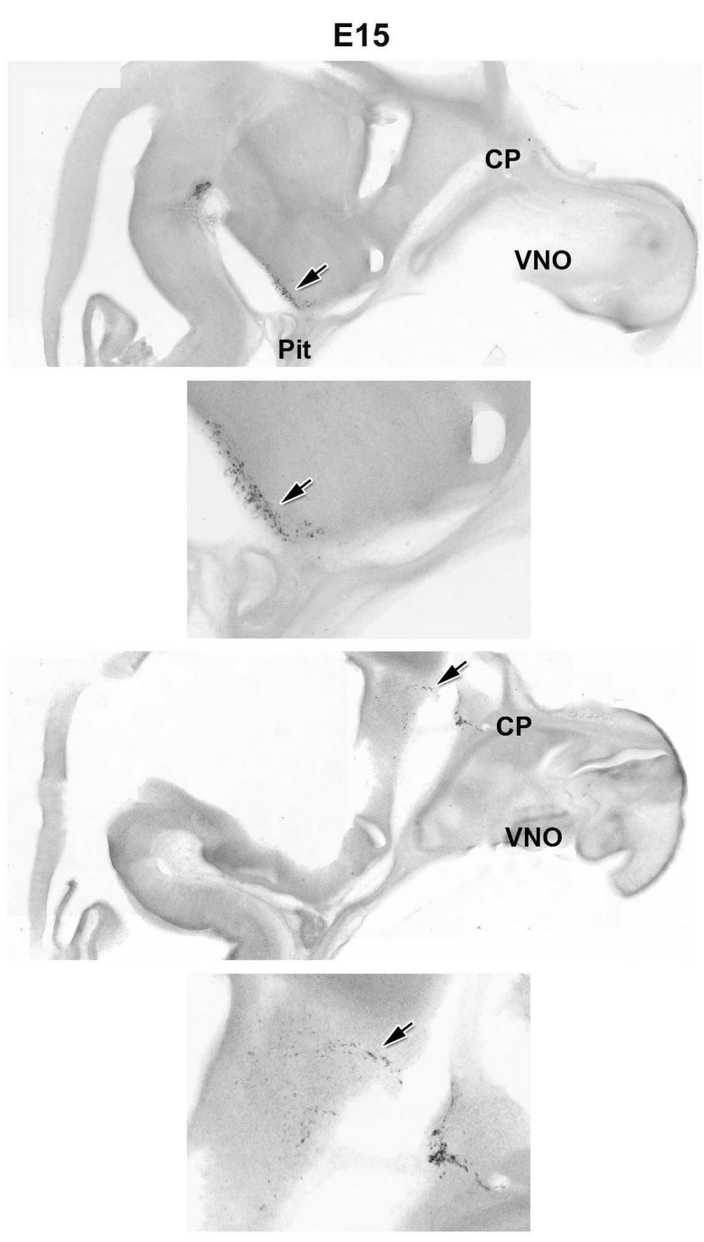

location of the Kiss1r positive cells from the nasal compartment to the forebrain between $\mathrm{E} 13$ and $\mathrm{E} 15$ reminiscent of the migrating $\mathrm{GnRH}$ neuron population. Arrows indicate the location of mRNA positive cells. CP, cribriform plate; Pit, pituitary; VNO, vomeronasal organ. Scale Bars: black $=1 \mathrm{~mm}$, white $=200 \mu \mathrm{m}$.

Kiss1r (C) shows that, in fact, cells expressing Kiss1r at E15 were migrating GnRH neurons.

To determine if Kiss1 is translated into processed KISS1 peptide during development, serial sections from fetal (E17) brains were examined by IHC. Immunoreactive kisspeptin (KISS1; Figures 3B,D) was detected using an antiserum raised against the biologically active decapeptide. A similar distribution to that seen using ISH was observed (Figures 3A,C). In fetal mice, KISS1 was only found in a distribution of cells in the ARC, and cell bodies were clearly identifiable in fetal ARC.

\section{RELATIVE DIFFERENCES IN KISS1 LOCALIZATION PATTERNS IN MOUSE FETAL AND EARLY POST-NATAL BRAIN}

For the ages of E15 (Figure 2) and E17 (Figure 4) the pattern of cells expressing Kiss1 remained unchanged. In addition, there appeared no sex difference in the number of cells expressing Kiss1 (E15 not shown; E17, Figure 4). At P12, the number of cells expressing Kiss 1 was dramatically higher in the female compared 


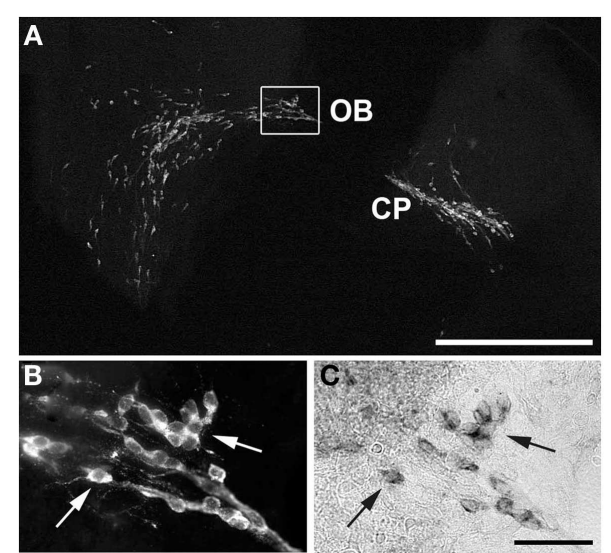

FIGURE 2 | Co-localization of GnRH and Kiss1r in migrating neurons. Kiss $1 r$ and $\mathrm{GnRH}$ were co-localized in migrating $\mathrm{GnRH}$ neurons in $\mathrm{E} 15$ mice. (A) shows a digital image of a fluorescent $\mathrm{IHC}$ for $\mathrm{GnRH}$ in a sagittal section from an E15 female also positive for Kiss1r. (B) (GnRH) and (C) (Kiss1r) show higher magnification images of the boxed area in (A), with arrows to indicate co-expressing cells. Compare the $\mathrm{GnRH}$ pattern in A to the Kiss $1 r$ pattern seen in the bottom right corner of Figure 1. $\mathrm{CP}$, cribriform plate; $\mathrm{OB}$, olfactory bulb. Scale Bars: white $=500 \mu \mathrm{m}$, black $=100 \mu \mathrm{m}$.

to the male. This is the only age examined at which there was a significant sex difference in the detectable number of cells expressing Kiss 1 in and around the ARC [Figure 4; $F(1,4)=8.2, p<0.05$ ]. There was no sex difference in the number of cells expressing Kiss1 at E13, E15, E17, or P35 (Figure 4).

In rostral sections, Kiss1 was first detected using ISH in a few cells at P12 (Figure 5). As with the more caudal ARC population, there was a distribution of cells in the rostral sections that begins near the opening of the third ventricle and extends caudally in a continuous cluster beyond the level of the anterior commissure. For the entire distribution, Kiss 1 was found in cell bodies along a narrow periventricular strip noted as the rostral periventricular region of the third ventricle (RP3V) (4). At P12 there was not a statistically significant sex difference in the number of cells found in the rostral population of cells. At P35 there appeared dramatically more cells in RP3V sections in both sexes as well as a significant sex difference in the number of cells found in these sections [Figure 5; $F(1,4)=262.0, p<0.01$ ], but no difference in the total number of cells in the ARC sections [Figure 5; $F(1,4)=1.83, p=0.25$ ].

\section{SEX DIFFERENCES IN ABSOLUTE Kiss1 AMOUNT IN FETAL AND ADULT MOUSE BRAIN}

Quantitative reverse transcription real-time PCR was used to assess the absolute level of Kiss1 in E17 and P50 (young adult) male and female GnRH-eGFP mice. As previous results suggested, and in agreement with the current ISH data, adult females expressed nearly four times as much Kiss 1 as males in the RP3V [Figure 6; $F(1,4)=9.77 ; p<0.05]$. In the caudal hypothalamic region of the adult animals, females were found to express more than twice as much transcript as males [Figure 6; $F(1,4)=43.1, p<0.01$ ]. A similar difference was found in the E17 animals, when Kiss 1 expression is restricted to the caudal region around the ARC, with females expressing more than twice as much Kiss1 as males [Figure 6;
$F(1,6)=22.1 ; p<0.01]$. Females were not examined at the time of dissection to determine estrous stage. In a final comparison, and in agreement with the increase in cell count with age, the level of Kiss 1 expression was significantly different between fetal and adult animals [Figure 6; age effect: $F(1,10)=41.01, p<0.01$; sex by age effect; $F(1,10)=10.26, p<0.01]$.

\section{POTENTIAL SOURCE OF SEX DIFFERENCES IN Kiss1 IN FETAL MOUSE BRAIN}

To determine if the sex difference of Kiss 1 in ARC neurons was related to steroid hormones or gonadal status of fetal mice, we conducted Kiss1 ISH analyses of Sf1 KO XY mice (agonadal due to disruption of the $S f 1$ gene but genetically male) compared with XY and XX WT littermates. $S f 1 \mathrm{KO}$ mice die shortly after birth due to the absence of adrenal hormones, and thus without glucocorticoid supplementation these animals can only be evaluated at embryonic ages $(24,25)$. However, the advantage of using these animals is that the effects of total gonadal ablation can be achieved from the earliest stage of development, before surgical gonadectomy is possible. In each experiment, sections from $S f 1 \mathrm{KO} \mathrm{XY}$ mice were most comparable to sections from WT XX mice by qualitative visual inspection of the optical density of reaction product (Figure 7). Cells observed in sections from WT XY mice were consistently lighter in color than either WT XX or XY Sf1 KO mice.

To verify that the visual ISH difference represents an actual difference in Kiss1, QPCR was performed on cDNA from hypothalamic tissue dissections from E17 XY and XX Sf1 KO and WT littermates. There was a sex difference in Kiss1 copy number between XY and XX WT mice from the Sf1 KO line $(p<0.05$ post hoc) that was similar to the results from the previous QPCR experiments using GnRH-eGFP animals. Importantly, there was a significant sex by genotype interaction [Figure $7 ; F(1,8)=6.56$; $p=0.034]$ with XY WT mice expressing significantly less Kiss 1 than XY KO, but with no difference between XX WT and XX KO. Thus the impact of the KO was only seen in males that may have had functional gonads.

\section{DISCUSSION}

An increasing number of studies have indicated the importance of kisspeptin signaling for both the onset of puberty and the promotion of normal adult reproduction $(1,26)$. Several have demonstrated the sex-steroid dependence of peri-pubertal changes in Kiss1 expression and sexually dimorphic Kiss 1 expression in the rostral hypothalamus $(11,27)$. However, despite the pre-pubertal sex differences in circulating sex steroids, most notably at certain perinatal "critical periods," until recently few studies have investigated the early developmental expression of Kiss1 and its cognate receptor KISS1R $(12,28)$.

In the last few years a growing body of research has begun to shed light on the emerging understanding that the kisspeptin system is actively regulated long before puberty. Several recent reports have examined the expression of Kiss 1 early in life. In a study of the ontogeny of kisspeptin neurons using BrdU birth dating in rats, these neurons differentiate locally within the region of the ARC beginning around E12.5 (29). Kiss1 was present in hypothalamic micropunches and KISS1 immunoreactive cells and fibers were detected as early as E14.5. Importantly, by showing that the 

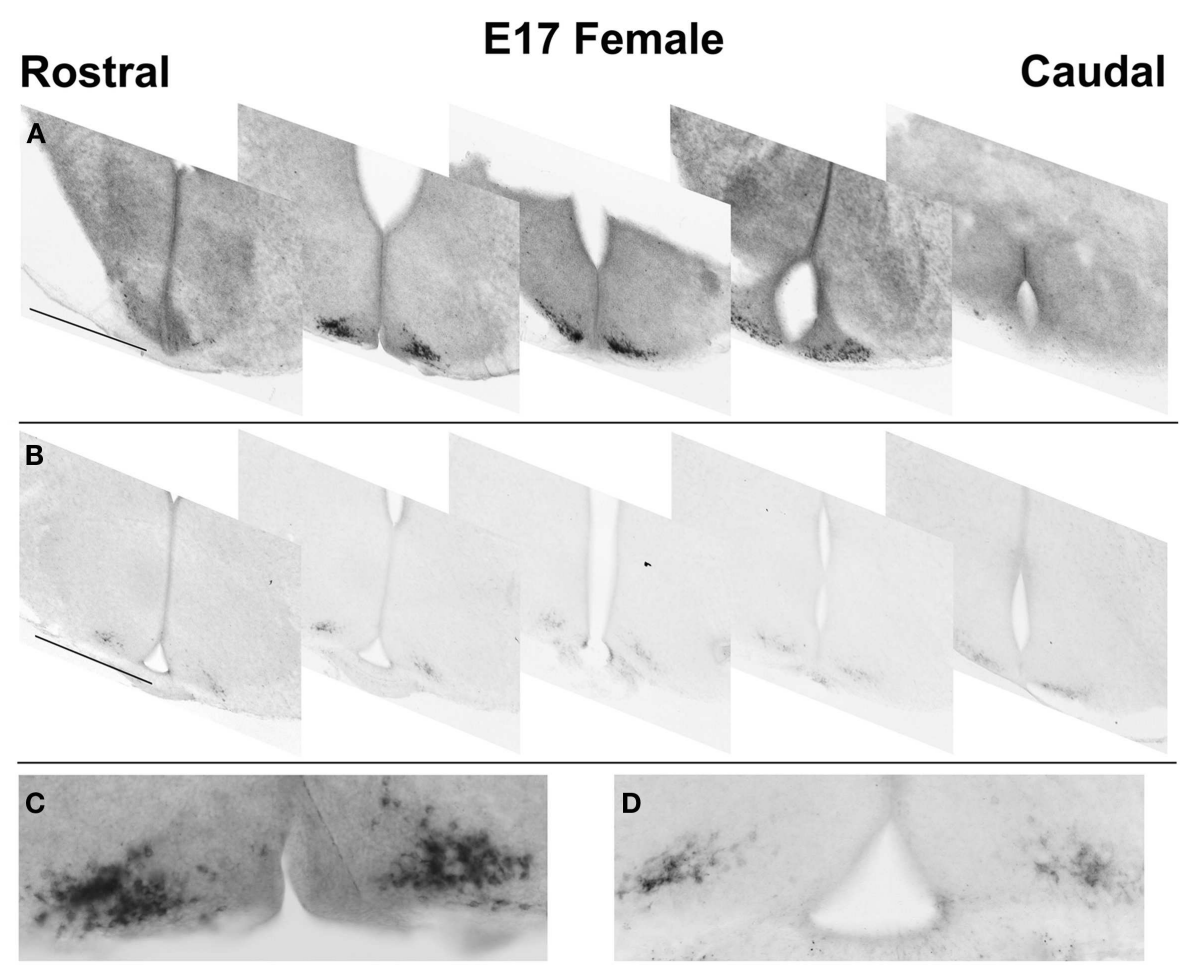

FIGURE 3 | Embryonic distribution of Kiss1/KISS1 expressing

cells. Digital images of representative sections showing the rostral-caudal distribution of cells expressing Kiss 1 (A) and kisspeptin-10 immunoreactivity (B) in the ARC. Expression extends over 800-1000 $\mu \mathrm{m}$. High magnification digital montages, taken from coronal plane 2 in (A,B), highlight differences in cell detail such as nuclear voids in ISH reaction product (C), but not IHC (D). Scale bars: $(\mathbf{A}, \mathbf{B})=500 \mu \mathrm{m} ;(\mathbf{C}, \mathbf{D})=250 \mu \mathrm{m}$. number of cells increased early in development (E14.5-18.5) and then decreased (E18.5-22.5) the data suggests pre-natal regulation of the kisspeptin system. Similar to these results, Kiss1 expressing neurons were detected via ISH soon after birth (first reported for P3) in the ARC of rats and there were transient sex differences in the number of Kiss 1 cells, with females having significantly more cells at certain times than their male littermates (30). Finally, in mice examined for Kiss 1 expression on the day of birth, both the number of Kiss 1 positive cells and the amount of Kiss1 per cell were higher in females than males (31). Interestingly, by examining the levels of circulating testosterone and using transgenic models with disrupted kisspeptin or GnRH signaling, the authors demonstrated that sex differences in gonadal steroid production arise independent of KISS1/KISS1R and GnRH.

In the current series of experiments, Kiss1 and Kiss1r were detected in E13 mouse brain tissue. Using IHC it was further demonstrated that Kiss 1 is translated into immunoreactive peptide as early as E17 and potentially earlier. This result is similar to findings of pre-natal kisspeptin expression in rats (29). The differences with our results, most notably that a small number of KISS1 IR cells and fibers were found in the RP3V pre-natally in rats, are likely due to species variation or differences in detection technique. The current results replicate earlier studies showing the sexually dimorphic number of Kiss 1 expressing cells in the ARC and RP3V of mice and rats $(5,31,32)$, but importantly show that there is already a sexually dimorphic pattern within the fetal ARC, whether examined qualitatively by visual inspection of colorimetric ISH (see Figure 7) or quantitatively using QPCR. Our data show sex differences in the amount of ARC Kiss1 at all ages examined, with RP3V expression only detected after birth. By using $S f 1 \mathrm{KO}$ mice that do not develop gonads, the early dependence of Kiss1 levels on gonadal status is strongly suggested. Although it is possible that knocking out Sf1 causes changes in Kiss 1 expression in gonad independent manner - such as preventing signaling within the mediobasal hypothalamus itself - this is unlikely considering that XX knockouts (KO) were not significantly different from their WT littermates. The demonstration of regulated Kiss 1 expression early in development suggests functional relevance that merits further investigation.

In an effort to better understand the development of sex differences in the brain's reproductive axis, the developmental profile of Kiss 1 expression using ISH was determined. Expression of Kiss 1 was found at E13 followed by a dramatic increase in the number of detectable cells positive for Kiss 1 by E15. This increase demonstrates an early expression of Kiss 1 , and also suggests a temporally coordinated up-regulation. From E15 to P0 there was no significant change in either the number of cells found to express Kiss1 or in the distribution pattern of these cells around the ARC (i.e., $\sim 400$ cells/half-brain distributed over $\sim 800 \mu \mathrm{m}$ rostrocaudally). Protein translation from Kiss1 was verified by IHC for KISS1 in E17 and adult animals where immunoreactive product was seen in a pattern similar to that seen with ISH. At all ages examined, mRNA coding 

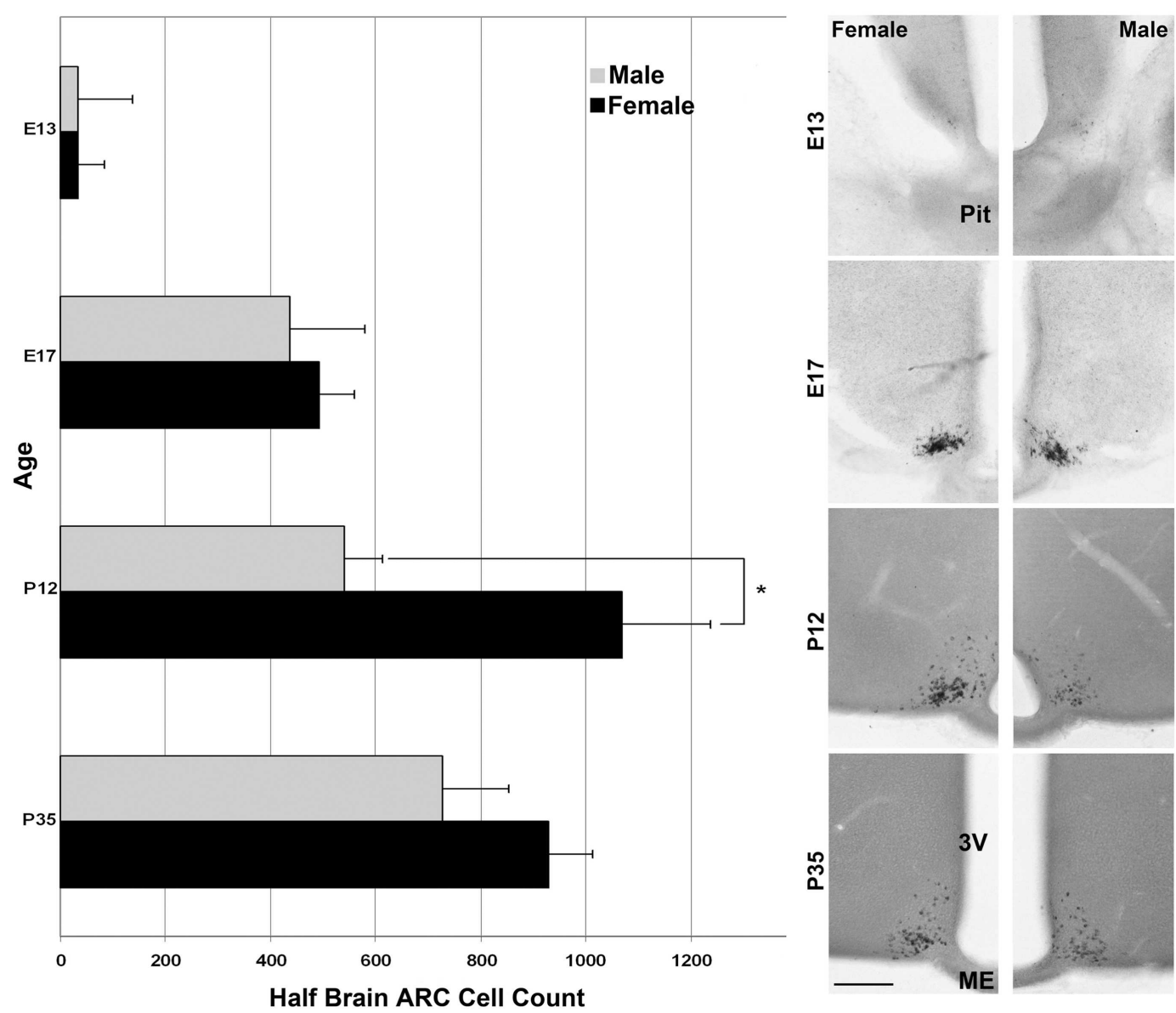

FIGURE 4 | Developmental changes in cells expressing Kiss 1 in the region of the ARC. The number of cells expressing Kiss 1 in and around the ARC differs with age ( $n=3$ per group) shown in coronal sections. A transient sex difference in the number of ARC cells was evident at P12 (mean \pm SEM; ${ }^{*} p<0.01$ ). Note the difference in the optical density of reaction product between males (images in the right column) and females (left column). This difference is most visibly evident at P12 and P35 but is notable at all ages examined at higher magnification. Pit, pituitary; $3 \mathrm{~V}$, third ventricle, $\mathrm{ME}$, median eminence. Scale bar $=100 \mu \mathrm{m}$. for the kisspeptin receptor KISS1R also was detected. The presence of both the ligand and cognate receptor establishes the possibility that a functional signaling system exists not only prior to puberty, but also well before birth. KISS1R is highly selective for kisspeptin when compared with all other RF-amide peptides. Similar to previous results, at E13 these cells were found exclusively in the nasal compartment in a distribution pattern that strongly resembles the migrating $\mathrm{GnRH}$ neuron population (33). Co-localization of immunoreactive GnRH and Kiss1r in E15 animals confirmed that cells seen to contain Kiss1r are, in fact, migrating GnRH neurons. Unfortunately, the absence of verified antibodies against KISS1R prevented the examination of the translation status of KISS1R.

Projections from neurons in the ARC may develop relatively late $(34,35)$. This would make ARC KISS1 an unlikely source of ligand for migrating $\mathrm{GnRH}$ neurons at embryonic ages, particularly when they are in the nasal compartment expressing Kiss1r. Previous results showing the efficacy of peripheral kisspeptin administration suggest that systemic, endocrine-like signaling, as opposed to synaptic release, could potentially play a role in development
(36). Other peripheral sources of kisspeptin are possible (e.g., placenta), which would suggest that signaling is not for the purpose of providing a directional cue for migrating $\mathrm{GnRH}$ neurons but could possibly influence axon targeting (37). Similar to previous findings, one additional population of Kiss1r expressing cells was found in the habenula (38). These cells are located at the approximate border of the medial and lateral divisions of the habenula and were seen from E17 on (though not noted in younger animals). It is interesting to note the role of the habenula in physiological changes related to seasonality and specifically in seasonal breeders $(36,39,40)$. While it remains to be determined where the ligand would come from to reach cells in the habenula expressing KISS1R, one possible source is the "estrogen concentrating cells" of the POA that send projections to the habenula (41-43). This also raises the possibility that patients with inactivating mutations of KISS1R or KISS1 may exhibit phenotypes other than those manifested in the reproductive system.

The data from older animals in the current study confirms the pattern of Kiss1 expression that has been reported previously (5, 

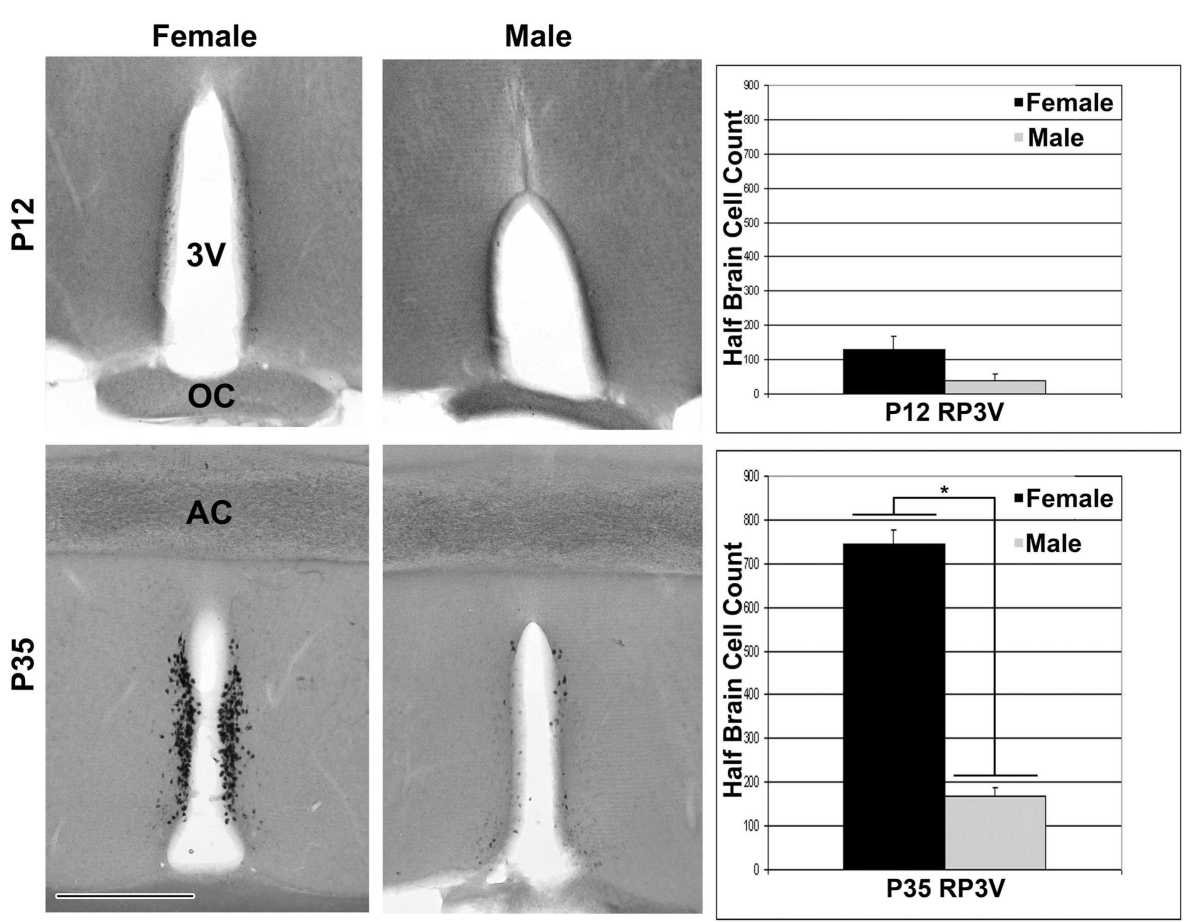

FIGURE 5 | Expression of Kiss1 in the RP3V. Digital images (left) of coronal sections show that Kiss 1 in the RP3V was first detected at P12. A dramatic sex difference in the number of cells expressing Kiss 1 was evident around the time of puberty onset in females, P35 (see graphs on the right; $n=3$ per group; mean \pm SEM; ${ }^{*} p<0.01$ ). $3 \mathrm{~V}$, third ventricle; OC, optic chiasm, $A C$, anterior commissure; Scale bar $=500 \mu \mathrm{m}$.
15, 44). Specifically, Kiss1 was observed in the ARC in both sexes at all post-natal ages in a pattern very similar to the fetal pattern. At P12 there was a significant sex difference in the number of Kiss 1 expressing cells in the ARC, with females having more cells than males. Since the number of cells in males is similar to that of females by the next time point (P35) it could simply indicate a sex difference in maturational rate, which would not be unusual for the development of brain characteristics (45). Similarly, it is possible that all post-natal sex differences observed in the ARC are due to differences in circulating sex steroids; several studies have shown that sex differences in Kiss1 expression in the RP3V are eliminated in mice and rats that have artificially equal levels of sex steroids $(5,14)$. Interestingly, P12 is the first age at which Kiss 1 expression was detected in a few cells in rostral sections. This result is similar to previously published research showing detection of Kiss 1 at P10 (32). At this age, possibly due to the apparently low level of message or the relatively low number of cells, there was no sex difference in the number of Kiss 1 containing cells seen in the RP3V. By contrast, at around the time of puberty onset (P35) there was a dramatic sex difference in the number of Kiss1 expressing cells in the RP3V, with females having far more cells than males.

In the current study, data from three different approaches suggest that the level of Kiss 1 in the ARC is a reliable sex difference in development and adulthood. First, qualitative differences were noted between males and females based on the optical density of ISH reaction product. Second, quantitative QPCR produced complementary results. The complementary nature of both ISH and QPCR assay was particularly evident at E17. Although the number

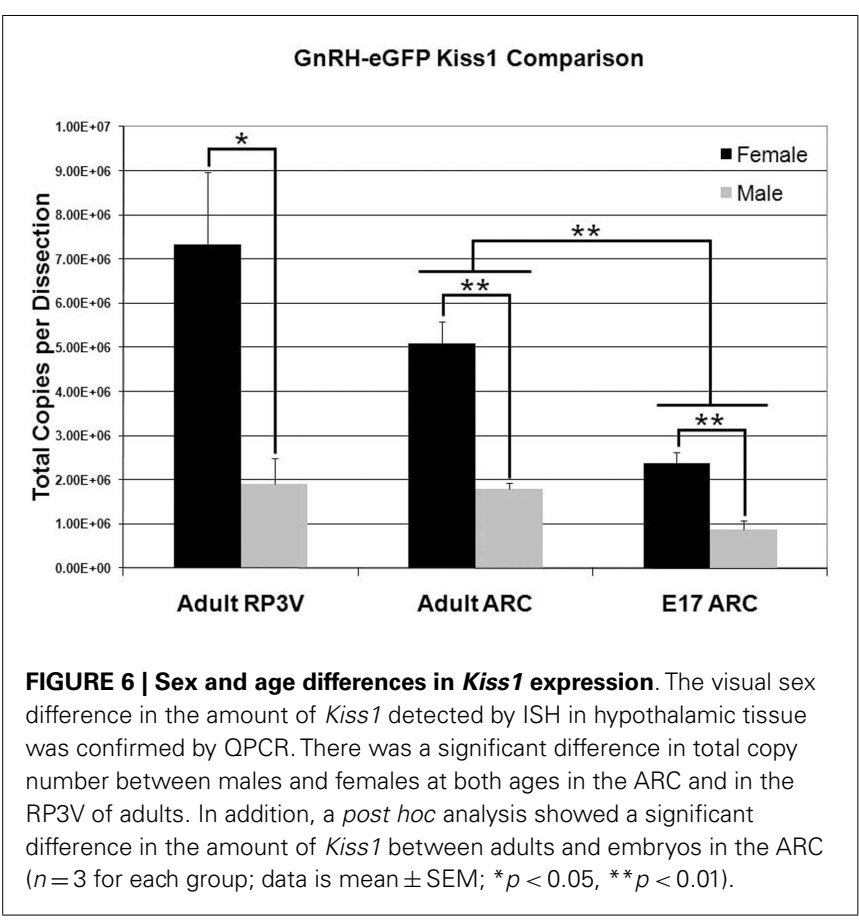

of cells positive for Kiss1 in the ARC appeared similar according to ISH, females had absolute levels of Kiss $1 \sim$ twofold greater than males according to QPCR and this difference remained at P35. As a verification of the method, the sex difference in adult Kiss 1 


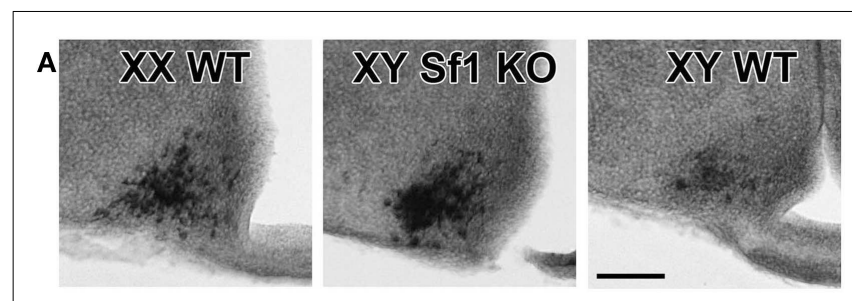

B

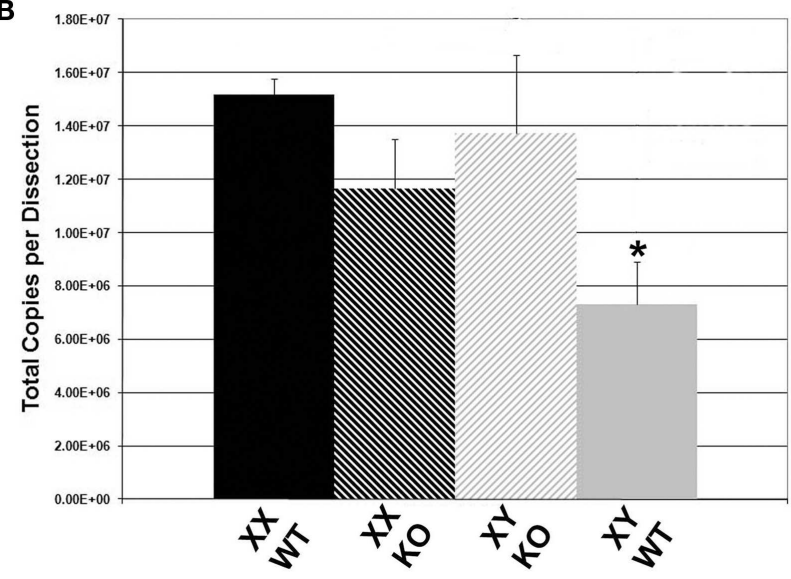

FIGURE 7 | Pre-natal Kiss1 expression is gonad dependent. Digital images of coronal sections in (A) show that E17 Sf1 KO XY resemble WT $X X$ more than WT XY mice by qualitative inspection of ISH reaction product. QPCR quantification of Kiss1 (B) reveals a significant effect of sex by genotype with WT males expressing less Kiss 1 than KO males or females of either genotype ( $n=3$ per group; mean \pm SEM. After a significant interaction between sex and genotype, ${ }^{*} p<0.05$ indicates a specific of $X Y$ $\mathrm{KO}$ to $X X W T$. $3 \mathrm{~V}$, third ventricle; $\mathrm{ME}$, median eminence. Scale bar $=100 \mu \mathrm{m}$.

levels within the more rostral RP3V was approximately fourfold as expected from data in reports for either whole hypothalamus or RP3V, respectively $(28,46)$. It should be noted that the adult females used for QRCR experiments were not examined to determine which stage of the estrous cycle they were in at the time of sacrifice, nor were circulating levels of sex steroids measured in either males or females. It has been established that Kiss1 levels depend on levels of circulating sex steroids and varies dramatically during the estrous cycle in both RP3V and ARC (47). It is possible that the observed sex differences are due, fully or in part, to differences in circulating levels of sex steroids. Finally, as many sex differences in adulthood are the direct result of differences in the

\section{REFERENCES}

1. Clarkson J, Herbison AE. Oestrogen, kisspeptin, GPR54 and the pre-ovulatory luteinising hormone surge. J Neuroendocrinol (2009) 21(4):305-11. doi:10.1111/j.13652826.2009.01835.x

2. Christensen A, Bentley GE, Cabrera R, Ortega HH, Perfito N, Wu $\mathrm{TJ}$, et al. Hormonal regulation of female reproduction. Horm Metab Res (2012) 44(8):587-91. doi:10. 1055/s-0032-1306301 Smith JT, Popa SM, Acohido BV, Crowley WF, et al. A role for kisspeptins in the regulation of gonadotropin secretion in the mouse. Endocrinology (2004) 145(9):4073-7. doi:10.1210/en.2004-0431

4. Herbison AE. Estrogen positive feedback to gonadotropin-releasing hormone $(\mathrm{GnRH})$ neurons in the rodent: the case for the rostral periventricular area of the third
3. Gottsch ML, Cunningham MJ,

steroid environment of the fetus (48), agonadal Sf1 KO mice were used to further test the gonadal steroid dependence of pre-natal Kiss 1 expression. The intensity of ISH reaction product revealed that Sf1 KO XY mice were more similar to XX WT rather than XY WT mice, suggesting that the level of Kiss 1 expression is directly dependent on the gonadal status and presumably the pre-natal steroid environment.

Pre-natal sexual differentiation of the rodent brain is largely driven by testosterone produced by the developing testes that is converted to estradiol within the brain itself. Female fetuses are protected from masculinization and defeminization by circulating alpha-fetoprotein which binds circulating estrogens and prevents it from acting in the brain (49). Based on the finding that estradiol administration to adult animals decreases ARC Kiss1 expression while increasing expression in the RP3V (5, 14 ), it is reasonable to speculate that testosterone derived estradiol inhibits Kiss 1 expression in male fetuses. This also implies that there is another mechanism in addition to estradiol stimulation that drives expression of kisspeptin in the RP3V as no rostral Kiss1 expression was detected in any animals, regardless of genotype, prior to P12. If estradiol signaling were the only driving force for RP3V expression, it would be reasonable to expect expression in fetal males. Previous studies have shown that the RP3V kisspeptin expressing population can be decreased by estradiol administration at birth $(50,51)$ or increased by neonatal castration (46), as well as decreased by gonadectomy later during pre-pubertal development (27). This may indicate that the RP3V population becomes sensitized to estradiol later during development and that other developmental events are required prior to puberty.

In summary, Kiss 1 and Kiss1r were detected in fetal mice early in development. Kiss1r was co-localized with GnRH in the nasal compartment and rostral forebrain during $\mathrm{GnRH}$ neuron migration, while Kiss 1 was found selectively in cells within the developing ARC. At E17 KISS1 was observed in the same region and distribution as the mRNA. Kiss1 expression was both qualitatively and quantitatively sexually dimorphic, and likely related to hormone exposure prior to birth. The sex difference in this region is maintained into adulthood, although the exact cause and function of this early kisspeptin expression remains to be elucidated.

\section{ACKNOWLEDGMENTS}

This work was supported by NIDCD grant \#DC009034 (Gerald A. Schwarting, Stuart A. Tobet) and NIMH MH61376 (Stuart A. Tobet).

ventricle (RP3V). Brain Res Rev (2008) 57(2):277-87. doi:10.1016/j. brainresrev.2007.05.006

5. Kauffman AS, Gottsch ML, Roa J, Byquist AC, Crown A, Clifton DK, et al. Sexual differentiation of Kiss1 gene expression in the brain of the rat. Endocrinology (2007) 148(4):1774-83. doi:10. 1210/en.2006-1540

6. Roseweir AK, Millar RP. The role of kisspeptin in the control of gonadotrophin secretion. Hum Reprod Update (2009) 15(2):203-12. doi:10.1093/humupd/dmn058

7. Smith JT. Sex steroid regulation of kisspeptin circuits. Adv Exp Med Biol (2013) 784:275-95. doi:10. 1007/978-1-4614-6199-9_13

8. Seminara SB, Messager S, Chatzidaki EE, Thresher RR, Acierno JS Jr, Shagoury JK, et al. The GPR54 gene as a regulator of puberty. $N$ Engl J Med (2003) 349(17):1614-27. doi:10.1056/NEJMoa035322 
9. d'Anglemont de Tassigny X, Fagg LA, Dixon JP, Day K, Leitch HG, Hendrick AG, et al. Hypogonadotropic hypogonadism in mice lacking a functional Kiss1 gene. Proc Natl Acad Sci U S A (2007) 104(25):10714-9. doi:10. 1073/pnas.0704114104

10. Lapatto R, Pallais JC, Zhang D, Chan YM, Mahan A, Cerrato F, et al. Kiss1 ${ }^{-1-}$ mice exhibit more variable hypogonadism than $\mathrm{Gpr} 54^{-/-}$mice. Endocrinology (2007) 148(10):4927-36. doi:10.1210/en.2007-0078

11. Poling MC, Kauffman AS. Organizational and activational effects of sex steroids on kisspeptin neuron development. Front Neuroendocrinol (2013) 34(1):3-17. doi:10. 1016/j.yfrne.2012.06.001

12. Semaan SJ, Tolson KP, Kauffman AS. The development of kisspeptin circuits in the Mammalian brain. Adv Exp Med Biol (2013) 784: 221-52. doi:10.1007/978-1-46146199-9 11

13. Smith JT, Popa SM, Clifton DK, Hoffman GE, Steiner RA. Kiss1 neurons in the forebrain as central processors for generating the preovulatory luteinizing hormone surge. J Neurosci (2006) 26(25):6687-94. doi:10.1523/ JNEUROSCI.1618-06.2006

14. Smith JT, Cunningham MJ, Rissman EF, Clifton DK, Steiner RA. Regulation of Kiss1 gene expression in the brain of the female mouse. Endocrinology (2005) 146(9):3686-92. doi:10.1210/en.2005-0323

15. Gill JC, Wang O, Kakar S, Martinelli E, Carroll RS, Kaiser UB. Reproductive hormone-dependent and independent contributions to developmental changes in kisspeptin in GnRH-deficient hypogonadal mice. PLOS ONE (2010) 5(7):e11911. doi:10.1371/journal. pone.0011911

16. Bakker J, Pierman S, GonzalezMartinez D. Effects of aromatase mutation (ArKO) on the sexual differentiation of kisspeptin neuronal numbers and their activation by same versus opposite sex urinary pheromones. Horm Behav (2010) 57(4-5):390-5. doi:10.1016/ j.yhbeh.2009.11.005

17. Suter KJ, Song WJ, Sampson TL, Wuarin JP, Saunders JT, Dudek FE, et al. Genetic targeting of green fluorescent protein to gonadotropin-releasing hormone neurons: characterization of whole-cell electrophysiological properties and morphology.
Endocrinology (2000) 141(1):412-9. doi:10.1210/en.141.1.412

18. Luo X, Ikeda Y, Parker KL. A cell-specific nuclear receptor is essential for adrenal and gonadal development and sexual differentiation. Cell (1994) 77(4):481-90. doi: 10.1016/0092-8674(94)90211-9

19. Theiler K. The House Mouse: Atlas of Embryonic Development. New York: Springer-Verlag (1989).

20. Knoll JG, Wolfe CA, Tobet SA. Estrogen modulates neuronal movements within the developing preoptic area-anterior hypothalamus. Eur J Neurosci (2007) 26(5):1091-9. doi:10.1111/j.1460-9568.2007. 05751.x

21. Dellovade TL, Young M, Ross EP, Henderson R, Caron K, Parker $\mathrm{K}$, et al. Disruption of the gene encoding SF-1 alters the distribution of hypothalamic neuronal phenotypes. J Comp Neurol (2000) 423(4):579-89. doi:10.1002/10969861(20000807)423:4<579::AIDCNE4>3.0.CO;2- I\#

22. Tobet SA, Walker HJ, Seney ML, Yu KW. Viewing cell movements in the developing neuroendocrine brain. Integr Comp Biol (2003) 43:794-801. doi:10.1093/icb/43.6. 794

23. Franceschini I, Lomet D, Cateau M, Delsol G, Tillet Y, Caraty A. Kisspeptin immunoreactive cells of the ovine preoptic area and arcuate nucleus co-express estrogen receptor alpha. Neurosci Lett (2006) 401(3):225-30. doi:10.1016/ j.neulet.2006.03.039

24. Majdic G, Tobet S. Cooperation of sex chromosomal genes and endocrine influences for hypothalamic sexual differentiation. Front Neuroendocrinol (2011) 32(2):137-45. doi:10.1016/j.yfrne.2011.02.009

25. Budefeld T, Tobet SA, Majdic G. Steroidogenic factor 1 and the central nervous system. J Neuroendocrinol (2012) 24(1):225-35. doi: 10.1111/j.1365-2826.2011.02174.x

26. Han SK, Gottsch ML, Lee KJ, Popa SM, Smith JT, Jakawich SK, et al. Activation of gonadotropinreleasing hormone neurons by kisspeptin as a neuroendocrine switch for the onset of puberty. $J$ Neurosci (2005) 25(49):11349-56. doi:10.1523/JNEUROSCI.3328-05. 2005

27. Clarkson J, Boon WC, Simpson ER, Herbison AE. Postnatal development of an estradiolkisspeptin positive feedback mechanism implicated in puberty onset. Endocrinology
(2009)

150(7):3214-20. doi:10.1210/en.2008-1733

28. Navarro VM, Castellano JM, Fernandez-Fernandez R, Barreiro ML, Roa J, Sanchez-Criado JE, et al. Developmental and hormonally regulated messenger ribonucleic acid expression of KiSS-1 and its putative receptor, GPR54, in rat hypothalamus and potent luteinizing hormonereleasing activity of KiSS-1 peptide. Endocrinology (2004) 145(10):4565-74. doi:10.1210/en. 2004-0413

29. Desroziers E, Droguerre $M$, Bentsen AH, Robert V, Mikkelsen JD, Caraty A, et al. Embryonic development of kisspeptin neurones in rat. $J$ Neuroendocrinol (2012) 24(10):1284-95. doi:10 1111/j.1365-2826.2012.02333.x

30. Takumi K, Iijima N, Ozawa H. Developmental changes in the expression of kisspeptin mRNA in rat hypothalamus. J Mol Neurosci (2011) 43(2):138-45. doi:10.1007/s12031010-9430-1

31. Poling MC, Kauffman AS. Sexually dimorphic testosterone secretion in prenatal and neonatal mice is independent of kisspeptin-Kiss1r and GnRH signaling. Endocrinology (2012) 153(2):782-93. doi:10.1210/ en.2011-1838

32. Semaan SJ, Murray EK, Poling MC, Dhamija $S$, Forger NG, Kauffman AS. BAXdependent and BAX-independent regulation of Kiss1 neuron development in mice. Endocrinology (2010) 151(12):5807-17 doi:10.1210/en.2010-0783

33. Constantin S, Caligioni CS, Stojilkovic S, Wray S. Kisspeptin-10 facilitates a plasma membranedriven calcium oscillator in gonadotropin-releasing hormone-1 neurons. Endocrinology (2009) 150(3):1400-12. doi:10.1210/en.2008-0979

34. Bouret SG, Draper SJ, Simerly RB. Formation of projection pathways from the arcuate nucleus of the hypothalamus to hypothalamic regions implicated in the neural control of feeding behavior in mice. $J$ Neurosci (2004) 24(11):2797-805. doi:10. 1523/JNEUROSCI.5369-03.2004

35. Polston EK, Simerly RB. Ontogeny of the projections from the anteroventral periventricular nucleus of the hypothalamus in the female rat. $J$ Comp Neurol (2006) 495(1):122-32. doi:10.1002/cne.20874
36. Thompson EL, Patterson M, Murphy KG, Smith KL, Dhillo WS, Todd JF, et al. Central and peripheral administration of kisspeptin-10 stimulates the hypothalamic-pituitary-gonadal axis. J Neuroendocrinol (2004) 16(10):850-8. doi:10.1111/j.13652826.2004.01240.x

37. Fiorini Z, Jasoni CL. A novel developmental role for kisspeptin in the growth of gonadotrophin-releasing hormone neurites to the median eminence in the mouse. J Neuroendocrinol (2010) 22(10):1113-25. doi:10.1111/j.1365-2826.2010. 02059.x

38. Herbison AE, de Tassigny $\mathrm{X}$, Doran J, Colledge WH. Distribution and postnatal development of Gpr54 gene expression in mouse brain and gonadotropin-releasing hormone neurons. Endocrinology (2010) 151(1):312-21. doi:10.1210/ en.2009-0552

39. Sutherland RJ. The dorsal diencephalic conduction system: a review of the anatomy and functions of the habenular complex. Neurosci Biobehav Rev (1982) 6(1):1-13. doi:10.1016/01497634(82)90003-3

40. Yu EZ, Hallenbeck JM, Cai D, McCarron RM. Elevated arylalkylamine- $\mathrm{N}$-acetyltransferase (AA-NAT) gene expression in medial habenular and suprachiasmatic nuclei of hibernating ground squirrels. Brain Res Mol Brain Res (2002) 102(1-2):9-17. doi:10.1016/ S0169-328X(02)00138-9

41. King JC, Anthony EL, Gustafson AW, Damassa DA. Luteinizing hormone-releasing hormone (LH-RH) cells and their projections in the forebrain of the bat Myotis lucifugus lucifugus. Brain Res (1984) 298(2): 289-301. doi:10.1016/00068993(84)91428-8

42. Pfaff D, Keiner M. Atlas of estradiol-concentrating cells in the central nervous system of the female rat. $J$ Comp Neurol (1973) 151(2):121-58. doi:10.1002/cne.901510204

43. Stumpf WE. Estradiolconcentrating neurons: topography in the hypothalamus by dry-mount autoradiography. Science (1968) 162(857):1001-3. doi:10.1126/science.162.3857.1001

44. Clarkson J, Herbison AE. Postnatal development of kisspeptin neurons in mouse hypothalamus; sexual dimorphism and projections to gonadotropin-releasing hormone neurons. Endocrinology 
(2006) 147(12):5817-25. doi:10. 1210/en.2006-0787

45. Tobet SA, Hanna IK. Ontogeny of sex differences in the mammalian hypothalamus and preoptic area. Cell $\mathrm{Mol}$ Neurobiol (1997) 17(6):565-601. doi:10.1023/A:1022529918810

46. Homma T, Sakakibara M, Yamada S, Kinoshita M, Iwata K, Tomikawa J, et al. Significance of neonatal testicular sex steroids to defeminize anteroventral periventricular kisspeptin neurons and the GnRH/LH surge system in male rats. Biol Reprod (2009) 81:1216-25. doi:10.1095/ biolreprod.109.078311

47. Smith JT. Kisspeptin signalling in the brain: steroid regulation in the rodent and ewe. Brain Res Rev (2008) 57(2):288-98. doi:10.1016/j. brainresrev.2007.04.002
48. Phoenix CH, Goy RW, Gerall AA, Young WC. Organizing action of prenatally administered testosterone propionate on the tissues mediating mating behavior in the female guinea pig. Endocrinology (1959) 65:369-82. doi:10.1210/endo-65-3-369

49. Lenz KM, Nugent BM, McCarthy MM. Sexual differentiation of the rodent brain: dogma and beyond. Front Neurosci (2012) 6:26. doi:10. 3389/fnins.2012.00026

50. Navarro VM, Sanchez-Garrido MA, Castellano JM, Roa J, GarciaGaliano D, Pineda R, et al. Persistent impairment of hypothalamic KiSS-1 system after exposures to estrogenic compounds at critical periods of brain sex differentiation. Endocrinology (2009) 150(5):2359-67. doi:10.1210/en.2008-0580
51. Bateman HL, Patisaul HB. Disrupted female reproductive physiology following neonatal exposure to phytoestrogens or estrogen specific ligands is associated with decreased $\mathrm{GnRH}$ activation and kisspeptin fiber density in the hypothalamus. Neurotoxicology (2008) 29(6):988-97. doi:10.1016/j.neuro. 2008.06.008

Conflict of Interest Statement: The authors declare that the research was conducted in the absence of any commercial or financial relationships that could be construed as a potential conflict of interest.

Received: 09 April 2013; accepted: 24 September 2013; published online: 11 October 2013.
Citation: Knoll JG, Clay CM, Bouma GJ, Henion TR, Schwarting GA, Millar $R P$ and Tobet SA (2013) Developmental profile and sexually dimorphic expression of Kiss1 and Kiss1r in the fetal mouse brain. Front. Endocrinol. 4:140. doi: 10.3389/fendo.2013.00140

This article was submitted to Experimental Endocrinology, a section of the journal Frontiers in Endocrinology. Copyright (C) 2013 Knoll, Clay, Bouma Henion, Schwarting, Millar and Tobet. This is an open-access article distributed under the terms of the Creative Commons Attribution License (CC BY). The use, distribution or reproduction in other forums is permitted, provided the original author(s) or licensor are credited and that the original publication in this journal is cited, in accordance with accepted academic practice. No use, distribution or reproduction is permitted which does not comply with these terms. 